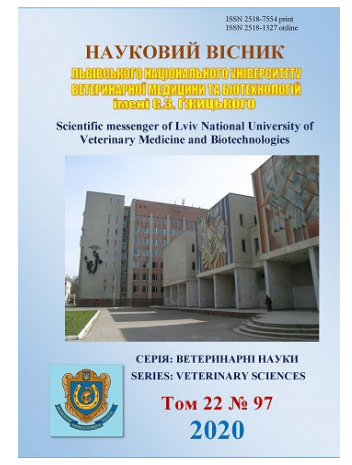

\author{
Науковий вісник Дьвівського національного університету \\ ветеринарної медицини та біотехнологій імені С.З. Гжицького. \\ Серія: Ветеринарні науки
}
Scientific Messenger of Lviv National University of Veterinary Medicine and Biotechnologies. Series: Veterinary sciences

\title{
Physiological state of the broiler chickens organism on the background of combined stress and additive of humic acids and probiotic
}

\author{
V. G. Stoyanovskyy, M. O. Shevchuk, I. A. Kolomiiets \\ Stepan Gzhytskyi National University of Veterinary Medicine and Biotechnologies, Lviv, Ukraine
}

Article info

Received 17.02.2020

Received in revised form 19.03 .2020

Accepted 20.03.2020

Stepan Gzhytskyi National University of Veterinary Medicine and Biotechnologies Lviv, Pekarska Str., 50, Lviv, 79010, Ukraine.

Tel.: +38-067-112-41-45

E-mail: kolomieciryna@gmail.com
Stoyanovskyy, V. G., Shevchuk, M. O., \& Kolomiiets, I. A. (2020). Physiological state of the broiler chickens organism on the background of combined stress and additive of humic acids and probiotic. Scientific Messenger of Lviv National University of Veterinary Medicine and Biotechnologies. Series: Veterinary sciences, 22(97), 157-161. doi: 10.32718/nvlvet9725

The cultivation of broiler chickens is cost-effective given the high reproductive quality and growth rate of young growth at an early age. However, the management of the industry involves a number of technological operations that cause excessive stress on the adaptive systems, decrease the immunobiological reactivity of the bird organism, the development of stress and cause a decline in egg and meat productivity. Under these conditions, it is necessary to strengthen and stimulate the resistance of the body of the bird, to determine ways to eliminate the development of stressful states by providing full feeding. Therefore, the purpose of the study was to determine the morpho-functional status of the body of broiler chickens against the background of combined stress when included in the diet of humic acids "Reasil Humic Vet", "Reasil Humic Health" and probiotics "Laktin". For the 13th day of life, all livestock in a clinically healthy poultry were subjected to combined stress - revaccination (intranasal against Newcastle disease) + cold stress (for 60 min by conditioning the room and reducing the vivarium temperature by $5{ }^{\circ} \mathrm{C}$ ). The study material was sampled 3 days after exposure to stress (corresponding to the anxiety stage), at 13,20, and 26 days after exposure to stress (which accounted for the various stages of resistance stage development). It is established that the morpho-functional status of the body of broiler chickens on the background of combined stress is characterized at the stage of anxiety by reducing the concentration of hemoglobin and hematocrit by an average of $16.6 \%$, increasing the number of eosinophils and pseudo-eosinophils; at various stages of development of the stage of resistance - decrease in the number of red blood cells and hemoglobin concentration by 3.4-6.5\% against the background of increase of hematocritic value by $37.0 \%$, increase in the number of leukocytes by $17.2 \%$ with a slight stabilization of respiratory and protective function of blood due to 26 days after stress. Influencing the formation of adaptive reactions of the body of broiler chickens of the experimental groups in the conditions of development of adaptation syndrome positive influence of the use of new biostimulants of natural origin "Reasil Humic Vet", "Laktin" and "Reasil Humic Health" is shown, which is shown by the increase of hemoglobin concentration on average $13.0 \%(P<0.05)$, leukocyte count by $25.4 \%(P<0.05)$ due to lymphocytes 1.1 times $(P<0.05)$.

Key words: broiler chickens, vaccination, cold stress, adaptation, humic acids, probiotic.

\section{Фізіологічний стан організму курчат-бройлерів на тлі комбінованого стресу при включенні в раціон гумінових кислот та пробіотика}

\author{
В. Г. Стояновський, М. О. Шевчук, І. А. Коломієць
}

Львівський національний університет ветеринарної медицини та біотехнологій імені С. 3. Гжиџького, м. Львів, Украӥна

Вирощування курей-бройлерів виступає рентабельним з огляду на високі відтворювальні якості та інтенсивність росту молодняку в ранньому віці. Проте, ведення галузі включає ряд технологічних операцій, які викликають надмірне напруження пристосу- 
вальних систем, зменшення імунобіологічної реактивності організму птиці, розвиток стресу $і$ зумовлюють зниження яєчної $i$ м'ясної продуктивності. За таких умов необхідно зміцнювати і стимулювати резистентність організму птиці, визначити способи усунення розвитку стресових станів за рахунок забезпечення повноцінної годівлі. Тому метою роботи було з'ясувати морфофункціональний статус організму курчат-бройлерів на тлі комбінованого стресу при включенні в рачіон гумінових кислот "Rеаsіl Humic Vet”, “Reasil Humic Health” та пробіотика “Laktin”. На 13 добу життя все поголів'я клінічно здорової птииі піддавалося дії комбінованого стресу - ревакцинація (інтраназальним методом проти хвороби Ньюкасла) + холодовий стрес (протягом 60 хв шляхом кондиціонування приміщення та зниження температури повітря у віварії на $\left.5{ }^{\circ} \mathrm{C}\right)$. Матеріал для досліджень відбирали на 3 добу після дії стрес-фактора (що відповідало стадії тривоги), на 13, 20 і 26 добу після дї стрес-фактора (щуо припадало на різні етапи розвитку стадії резистентності). Встановлено, шчо морфо-функціональний статус організму курчат-бройлерів на тлі дії комбінованого стресу характеризується на стадї тривоги зниженням концентрації гемоглобіну та величини гематокриту в середньому на 16,6 \%, збільшенням кількості еозинофілів і псевдоеозинофілів; на різних етапах розвитку стадї резистентності зниженням кількості еритроцитів та концентрації гемоглобіну на 3,4-6,5 \% на тлі підвищення гематокритної величини на $37,0 \%$, підвищення кількості лейкочитів на 17,2\% з незначною стабілізацією дихальної та захисної функції крові через 26 діб після дї стресу. Впливаючи на формування пристосувальних реакцій організму курчат-бройлерів дослідних груп в умовах розвитку адаптаційного синдрому встановлено позитивний вплив застосування нових біостимуляторів природного походження “Rеаліl Нитіс Vet", "Laktin” ma "Reasil Humic Health”, шьо проявляється підвищенням концентрації гемоглобіну в середньому на 13,0 \% (P <0,05), кількості лейкочитів на 25,4\% $(P<0,05)$ за рахунок лімфоцитів в 1,1 раза $(P<0,05)$.

Ключові слова: курчата-бройлери, вакцинація, холодовий стрес, адаптація, гумінові кислоти, пробіотик.

\section{Ветуп}

Ефективність розвитку галузі птахівництва обумовлює економічну і продовольчу безпеку країни, а вирощування курей-бройлерів виступає рентабельним 3 огляду на високі відтворювальні якості та інтенсивність росту молодняку в ранньому віці (Osti et al., 2017; Chen et al., 2018). За даними літератури, фізіологічно обумовлені вікові періоди імунодепресивного стану організму курчат-бройлерів співпадають із 3-5, 14-28 та 40-50 добою, що пов'язано 3 ювенальною линькою, статевим дозріванням, початком яйцекладки і характеризуються порушенням метаболічних процесів, зниженням резистентності організму (Fisinin et al., 2015; Stojanovskij et al., 2018). Крім цього, ряд дослідників вважають, що ведення галузі включає ряд технологічних операцій, які викликають надмірне напруження пристосувальних систем, зменшення імунобіологічної реактивності організму птиці, розвиток стресу і зумовлюють зниження яєчної і м'ясної продуктивності (Pavlova, 2015; Stojanovskij et al., 2018). За таких умов при дії технологічних стрес-факторів, необхідно зміцнювати і стимулювати резистентність організму птиці, визначити способи усунення розвитку стресових станів за рахунок забезпечення повноцінної годівлі, а також включення в раціон біологічно активних кормових добавок природного походження (Olubodun et al., 2015; Gutyj et al., 2017; Kapustian et al., 2018).

Мета роботи - з'ясувати морфо-функціональний статус організму курчат-бройлерів на тлі комбінованого стресу при включенні в раціон гумінових кислот "Reasil Humic Vet", "Reasil Humic Health" та пробіотика "Laktin".

\section{Матеріал і методи досліджень}

Усі маніпуляції з курчатами проводили 3 дотриманням вимог "Свропейської конвенції про захист хребетних тварин, які використовуються для експериментальних і наукових цілей” (Страсбург, 1986), ухвали Першого національного конгресу 3 біоетики (Київ, 2001) - “Загальні етичні принципи експеримен- тів на тваринах" та 3 дотриманням принципів гуманності, викладеними у директиві Свропейської Спільноти. Дослід проведено на базі віварію Державного науково-дослідного контрольного інституту ветеринарних препаратів та кормових добавок на молодняку курчат-бройлерів кросу “Kobb-500”, 3 яких в 5добовому віці сформовано три групи - контрольну (К) і дві дослідні (Д, Д2) по 25 особин в кожній групі, підібраних за принципом аналогів. Все поголів'я птиці до постановки на дослід було вакциноване проти хвороби Марека, Ньюкасла та інфекційного бронхіту згідно терміну відповідних вакцинацій. Утримання птиці відповідало загальноприйнятим технологічним вимогам підлогового утримання з вільним доступом до напувалок та годівниць. 311 доби життя і до завершення експерименту (45 доба життя) додатково до стандартного раціону курчатам Д групи випоювали кормовий препарат "Reasil Humic Vet” у рідкій формі 3 розрахунку 100 мл/100 л води та пробіотичну кормову добавку "Laktin" з розрахунку 1-2 л/100 л води; курчатам Д г групи згодовували кормовий препарат "Reasil Humic Health" в сухій формі з розрахунку 12 кг/1 т корму згідно інструкцій. На 13 добу життя все поголів'я клінічно здорової птиці піддавалося дії комбінованого стресу - ревакцинація (інтраназальним методом проти хвороби Ньюкасла) + холодовий стрес (протягом 60 хв шляхом кондиціонування приміщення та зниження температури повітря у віварії на $5{ }^{\circ} \mathrm{C}$ ). Матеріал для досліджень відбирали на 3, 13, 20 і 26 добу після дії стрес-фактора: вказані періоди реалізації стрес реакцій запропоновані на основі результатів досліджень і розробок колективу кафедри нормальної та патологічної фізіології імені С. В. Стояновського (Stojanovskij et al., 2018). Забій проводили до ранкової годівлі після легкого ефірного наркозу шляхом декапітації по 5 курчат з кожної групи. Матеріалом для досліджень слугувала кров, в якій визначали кількість еритроцитів, лейкоцитів, лейкограму крові, концентрацію гемоглобіну, величину гематокриту за загальноприйнятими методиками (Vlizlo et al., 2012). 


\section{Результати та їх обговорення}

При дослідженні загальних фізіологічних показників на початкових етапах дії комбінованого стресу спостерігали пригнічення загального стану, що проявлялося скупчуванням, зниженням рівня споживання корму молодняку птиці, яке тривало до завершення першої доби. Одержані результати дослідження показників, що характеризують морфо-функціональний статус організму курчат-бройлерів за дії стресу на тлі включення в раціон добавок наведені у таблиці 1 і 2 . Аналізуючи дані таблиці 1 необхідно відмітити, що в крові курчат К групи через 3 доби після дії стресу, що відповідало стадії тривоги, абсолютні значення кількості еритроцитів, концентрації гемоглобіну та величини гематокриту перебували у межах фізіологічної норми, що підтверджувалося клініко-фізіологічним обстеженням стану здоров'я поголів'я птиці. Разом 3 тим, у курчат Д г групи на тлі збільшення кількості еритроцитів на $14,5 \%$ i величини гематокриту на 5,6 \%, спостерігали вірогідне зниження концентрації гемоглобіну на 17,1 \% (P < 0,05), порівняно з контролем. В курчат Д2 групи виявлено тенденцію до збільшення кількості еритроцитів на 15,8 \%, проте зниження концентрації гемоглобіну та величини гематокриту вказувало на послаблення кисневотранспортної функції крові.

\section{Таблиця 1}

Морфологічні показники крові курчат-бройлерів на тлі комбінованого стресу при включенні в раціон "Reasil Humic Vet" + "Laktin" та "Reasil Humic Health", $(\mathrm{M} \pm \mathrm{m}, \mathrm{n}=5)$

\begin{tabular}{|c|c|c|c|}
\hline Групи & $\begin{array}{c}\text { Кількість } \\
\text { еритроцитів, } \\
\text { Т/л } \\
\end{array}$ & $\begin{array}{c}\text { Концентрація } \\
\text { гемоглобіну, } \\
\text { г/л }\end{array}$ & $\begin{array}{c}\text { Величина } \\
\text { гематокриту, } \\
\% \\
\end{array}$ \\
\hline \multicolumn{4}{|c|}{ через 3 доби після дії стресу } \\
\hline $\mathrm{K}$ & $1,52 \pm 0,12$ & $56,25 \pm 2,93$ & $29,64 \pm 2,62$ \\
\hline$Д_{1}$ & $1,74 \pm 0,12$ & $46,63 \pm 2,03 *$ & $31,31 \pm 3,29$ \\
\hline$Д_{2}$ & $1,76 \pm 0,14$ & $53,50 \pm 4,18$ & $28,39 \pm 1,24$ \\
\hline \multicolumn{4}{|c|}{ через 13 діб після дії стресу } \\
\hline K & $1,47 \pm 0,09$ & $52,59 \pm 4,03$ & $40,62 \pm 3,68$ \\
\hline$Д_{1}$ & $2,16 \pm 0,12 *$ & $54,90 \pm 1,37$ & $44,08 \pm 2,16$ \\
\hline Д2 & $1,64 \pm 0,24$ & $54,06 \pm 2,98$ & $42,61 \pm 1,69$ \\
\hline \multicolumn{4}{|c|}{ через 20 діб після дії стресу } \\
\hline K & $1,58 \pm 0,09$ & $46,92 \pm 5,55$ & $22,09 \pm 2,11$ \\
\hline$Д_{1}$ & $1,78 \pm 0,21$ & $47,90 \pm 6,84$ & $21,57 \pm 0,81$ \\
\hline$Д_{2}$ & $1,73 \pm 0,12$ & $58,05 \pm 5,27^{*}$ & $20,06 \pm 0,81$ \\
\hline \multicolumn{4}{|c|}{ через 26 діб після дії стресу } \\
\hline $\bar{K}$ & $2,09 \pm 0,21$ & $75,42 \pm 2,41$ & $25,68 \pm 1,24$ \\
\hline$Д_{1}$ & $2,15 \pm 0,19$ & $85,23 \pm 3,94 *$ & $20,65 \pm 1,88$ \\
\hline$Д_{2}$ & $2,02 \pm 0,44$ & $84,17 \pm 3,38^{*}$ & $19,04 \pm 1,41^{*}$ \\
\hline
\end{tabular}

Примітка: тут і далі різниці статистично вірогідні по відношенню до К групи та позначені: $-\mathrm{P}<0,05$; ** $-\mathrm{P}<0,01$; $* * *-\mathrm{P}<0,001$

На початкових етапах розвитку стадії резистентності, що припадало на 13 добу після дії стресу, фізіологічний статус організму курчат К групи характеризувався зниженням кількості еритроцитів та концентрації гемоглобіну на 3,4-6,5\% на тлі підвищення гематокритної величини на 37,0 \%, що могло виступати ознакою розвитку стресової реакції. У курчат Д групи виявляли підвищення кількості еритроцитів на $46,9 \%$ (Р < 0,05), в той час коли вірогідних відхилень у величині досліджуваного показника птиці Д2 групи виявлено не було, що могло свідчити про стимулюючий вплив комплексного застосування гумінових кислот і пробіотика на еритроцитопоез (Mohammed et al., 2018).

Встановлено, що на 20 добу розвитку стадії резистентності в курчат К групи абсолютна величина кількості еритроцитів наближалася до числових значень стадії тривоги, а концентрація гемоглобіну та величина гематокриту знижувалися в середньому на 16,6 \%, що могло виступати ознакою розвитку постнатальної адаптації організму птиці (Nguyen et al., 2016). У курчат дослідних груп кількість еритроцитів була вищою в середньому на $12,7 \%$, величина гематокриту наближалася до контролю, а концентрація гемоглобіну була вищою, насамперед у Д2 групі птиці на 23,7 \% ( $<<0,05)$, що підтверджувало ефективність кормового препарату "Reasil Humic Health" на основі гумінових кислот, які впливають на процеси аеробного окиснення, рівень енергетичних процесів за участю глюкози та активність ферментативних систем організму (Hangalapura et al., 2004).

На 26 добу розвитку стадії резистентності в курчат К групи кількість еритроцитів і концентрація гемоглобіну були вищими відповідно на 37,5 і 34,1 \% порівняно з стадією тривоги, що могло свідчити про покращення дихальної функції крові, проте зниження величини гематокриту на 13,4 \% могло вказувати на тривалу адаптацію організму птиці до дії стресу. В курчат Д 1 і Д 2 групи кількість еритроцитів наближалася до контролю, проте концентрація гемоглобіну підвищувалася в середньому на 13,0 \% (P < 0,05), що свідчило про позитивний вплив кормових препаратів на величину концентрації гемоглобіну в умовах розвитку адаптаційного синдрому. Проте, виявлене зниження величини гематокриту в птиці дослідних груп, насамперед, Д 2 групи на 25,8 \% $(\mathrm{P}<0,05)$ могло бути обумовлено способом і формою застосування препарату "Reasil Humic Health".

В основі підтримки гомеостазу організму, як відомо, лежать складні регуляторні взаємозв'язки між крово- та лімфообігом, а також діяльністю органів імунної системи, що забезпечують стійкість птиці до дії стресів (Varkholiak et al., 2020). Аналізуючи дані таблиці 2 необхідно відмітити, що в крові курчат К групи через 3 доби після дії стресу, що відповідало стадії тривоги, кількість лейкоцитів становила $23,3 \pm 2,62$ Г/л, серед яких частка еозинофілів і псевдоеозинофілів перебувала в верхніх межах фізіологічної норми і складала відповідно 8,6 \pm 0,65 та 32,6 \pm 1,18 \%. Це вказувало на розвиток стресової реакції в їх організмі, оскільки, як відомо, кількість вище названих клітин білої крові збільшується за дії стресу на його початковому етапі (Tsiouris et al., 2015). В курчат $Д_{1}$ і Д 2 групи кількість лейкоцитів була вищою від контролю в середньому на 22,7 \% за рахунок лімфо- 
цитів в 1,1 раза, а в Д2 групі - ще й за рахунок моноцитів. Разом з тим, вірогідне зниження кількості еозинофілів в дослідних групах птиці в 1,3 раза $(\mathrm{P}<0,05)$ вказувало на знижену інтенсивність розвитку стресової реакції, що можна вважати позитивним ефектом застосованих препаратів.

На початкових етапах розвитку стадії резистентності, що припадало на 13 добу після дії стресу, кількість лейкоцитів в курчат К групи підвищувалася на $17,2 \%$ в основному за рахунок лімфоцитів в 1,2 раза порівняно з стадією тривоги (3 доба), що було позитивним явищем і могло бути обумовлено реакцією імунної системи організму на ревакцинацію. Підтвердженням цього могло служити суттєве зниження частки еозинофілів і псевдоеозинофілів що $є$ ознакою розвитку адаптаційного синдрому. В курчат Д 1 і Д групи кількість лейкоцитів була нижчою від контролю в середньому на 9,9 \% 3 деякими відмінностями у лейкограмі, що свідчило про різний вплив застосованих добавок. Що стосується еозинофілів і псевдоеозинофілів, то їх кількість збільшувалася відносно контролю, насамперед, в курчат Д2 групи в 1,5 та 1,2 раза $(\mathrm{P}<0,05)$. Можливо, така реакція могла свідчити про послаблення стресового стану в організмі птиці за використання препарату. Стосовно лімфоцитів, то їх кількість в курчат Д1 групи наближалася до контролю, а в Д2 групі була нижчою в 1,2 раза $(\mathrm{P}<0,05)$, що могло залежати від способу застосування добавок і форми їх використання.

\section{Таблиця 2}

Кількість лейкоцитів (Г/л) і величина лейкограми (\%) крові курчат-бройлерів на тлі комбінованого стресу при включенні в раціон "Reasil Humic Vet" + "Laktin” та "Reasil Humic Health", ( $\mathrm{M} \pm$ m, n = 5)

\begin{tabular}{|c|c|c|c|c|c|}
\hline Групи & Кількість лейкоцитів & Еозинофіли & Псевдоеозинофіли & Лімфоцити & Моноцити \\
\hline \multicolumn{6}{|c|}{ через 3 доби після дії стресу } \\
\hline K & $23,3 \pm 2,62$ & $8,6 \pm 0,65$ & $32,6 \pm 1,18$ & $51,2 \pm 2,48$ & $7,4 \pm 0,94$ \\
\hline$Д_{1}$ & $28,6 \pm 2,25$ & $6,4 \pm 0,50 *$ & $30,8 \pm 2,94$ & $56,6 \pm 2,34$ & $6,0 \pm 0,25$ \\
\hline $\mathrm{Д}_{2}$ & $25,3 \pm 3,39$ & $6,4 \pm 0,64 *$ & $29,4 \pm 1,88$ & $56,0 \pm 3,32$ & $8,0 \pm 0,30$ \\
\hline \multicolumn{6}{|c|}{ через 13 діб після дії стресу } \\
\hline $\mathrm{K}$ & $27,3 \pm 3,18$ & $5,2 \pm 0,94$ & $28,6 \pm 2,49$ & $59,4 \pm 1,88$ & $6,6 \pm 0,80$ \\
\hline$Д_{1}$ & $24,6 \pm 2,80$ & $6,0 \pm 0,63$ & $29,2 \pm 2,98$ & $59,4 \pm 2,49$ & $5,2 \pm 0,76$ \\
\hline$Д_{2}$ & $24,0 \pm 3,60$ & $8,0 \pm 0,25^{*}$ & $35,2 \pm 1,77^{*}$ & $50,0 \pm 1,32 *$ & $6,6 \pm 0,92$ \\
\hline \multicolumn{6}{|c|}{ через 20 діб після дії стресу } \\
\hline $\mathrm{K}$ & $25,2 \pm 2,65$ & $7,2 \pm 0,49$ & $36,0 \pm 3,63$ & $52,0 \pm 1,22$ & $4,6 \pm 0,34$ \\
\hline$Д_{1}$ & $29,1 \pm 3,86$ & $6,6 \pm 0,75$ & $31,4 \pm 2,71$ & $55,2 \pm 2,50$ & $6,6 \pm 0,60^{*}$ \\
\hline Д2 $_{2}$ & $30,0 \pm 1,73^{*}$ & $6,0 \pm 0,62$ & $31,6 \pm 2,39$ & $57,0 \pm 1,41 *$ & $5,2 \pm 0,89$ \\
\hline \multicolumn{6}{|c|}{ через 26 діб після дії стресу } \\
\hline K & $23,6 \pm 1,80$ & $6,0 \pm 0,40$ & $32,0 \pm 3,26$ & $56,6 \pm 1,09$ & $5,2 \pm 0,94$ \\
\hline Д1 & $29,6 \pm 1,12^{*}$ & $4,6 \pm 0,45^{*}$ & $29,6 \pm 2,11$ & $61,0 \pm 1,07^{*}$ & $4,6 \pm 0,73$ \\
\hline$\check{Д}_{2}$ & $27,3 \pm 2,50$ & $6,4 \pm 0,94$ & $31,4 \pm 2,56$ & $57,0 \pm 2,72$ & $5,0 \pm 0,60$ \\
\hline
\end{tabular}

На 20 добу розвитку стадії резистентності кількість лейкоцитів в курчат К групи була вищою на $8,2 \%$ в основному за рахунок псевдоеозинофілів в 1,1 раза порівняно зі стадією тривоги, що вказувало на підвищення природної резистентності організму птиці за рахунок гуморальних факторів, оскільки зменшення частки моноцитів в 1,6 раза виступало ознакою зниження клітинних механізмів захисту (Qureshi et al., 2018). В курчат дослідних груп кількість лейкоцитів була вищою від контролю, насамперед, в курчат Д 2 групи на 19,0 \% $(\mathrm{P}<0,05)$. Встановлено, що частка еозинофілів і псевдоеозинофілів була нижчою від контролю в 1,1 раза, що свідчило про позитивний вплив кормових препаратів на нівелювання наслідків стресової реакції в організм курчат. На це вказувало і зростання частки лімфоцитів насамперед в Д2 групі в 1,1 раза $(\mathrm{P}<0,05)$ і моноцитів насамперед в Д 1 групі в 1,4 раза $(\mathrm{P}<0,05)$, порівняно з контролем.

На 26 добу розвитку стадії резистентності в курчат К групи числові значення кількості лейкоцитів наближалися до стадії тривоги, функціональний стан організму характеризувався зниженням розвитку стресового синдрому: кількість еозинофілів була нижчою в 1,4 раза, кількість псевдоеозинофілів набли- жалася до вихідного стану, дещо підвищувалася кількість лімфоцитів та знижувалася частка моноцитів в 1,4 раза. Позитивну динаміку спостерігали в кількості білих клітин крові курчат Д1 групи, де кількість лейкоцитів була вищою на 25,4 \% $(\mathrm{P}<0,05)$ за рахунок лімфоцитів в 1,1 раза (Р $<0,05)$, що виступало ознакою підвищення імунного статусу їх організму і свідчило про позитивний вплив випоювання кормових добавок "Reasil Humic Vet" + "Laktin". Нівелювання наслідків стресового стану тут характеризувалося зниженням кількості еозинофілів в 1,3 раза $(\mathrm{P}<0,05)$ та псевдоеозинофілів в 1,1 раза. В птиці Д2 групи встановлено незначне підвищення кількості лейкоцитів, проте співвідношення різних форм білих клітин у числових значеннях наближалися до контролю, що вказувало на менш помітний вплив кормового препарату "Reasil Humic Health" на функціональний стан організму курчат в період розвитку адаптаційного синдрому.

\section{Висновки}

Встановлено, що морфо-функціональний статус організму курчат-бройлерів на тлі дії комбінованого 
стресу характеризується на стадії тривоги зниженням концентрації гемоглобіну та величини гематокриту в середньому на 16,6 \%, збільшенням кількості еозинофілів і псевдоеозинофілів; на різних етапах розвитку стадії резистентності -зниженням кількості еритроцитів та концентрації гемоглобіну на 3,4-6,5\% на тлі підвищення гематокритної величини на 37,0 \%, підвищення кількості лейкоцитів на 17,2 \% 3 незначною стабілізацією дихальної та захисної функції крові через 26 діб після дії стресу.

Впливаючи на формування пристосувальних реакцій організму курчат-бройлерів дослідних груп в умовах розвитку адаптаційного синдрому встановлено позитивний вплив застосування нових біостимуляторів природного походження "Reasil Humic Vet", "Laktin" та "Reasil Humic Health", що проявляється підвищенням концентрації гемоглобіну в середньому на $13,0 \%$ ( $\mathrm{P}<0,05)$, кількості лейкоцитів на 25,4\% $(\mathrm{P}<0,05)$ за рахунок лімфоцитів в 1,1 раза $(\mathrm{P}<0,05)$.

Перспективи подальших досліджень бачимо у досліджені стану імунологічної реактивності організму курчат-бройлерів у стресові періоди при включенні в раціон кормових добавок "Reasil Humic Vet" + "Laktin” та кормової добавки "Reasil Humic Health".

\section{References}

Osti, R., BhattaraiII, D., \& Zhou, D. (2017). Climatic Variation: Effects on Stress Levels, Feed Intake, and Bodyweight of Broilers. Brazilian Journal of Poultry Science, 19(3), 345-350. doi: 10.1590/1806-90612017-0494.

Chen, N. N., Liu, B., Xiong, P. W., Guo, Y., He, J. N., Hou, C. C., Ma, L. X., \& Yu, D. Y. (2018). Safety evaluation of zinc methionine in laying hens: Effects on laying performance, clinical blood parameters, organ development, and histopathology. Poultry Science, 97(4), 1120-1126. doi: 10.3382/ps/pex400.

Fisinin, V. I., \& Kavtarashvili, A. Sh. (2015). Heat stress in poultry: methods and techniques for prevention and alleviation (review). Agricultural BIology, 50(4), 431443. doi: 10.15389/agrobiology.2015.4.431.

Stojanovskij, V. G., Krogh, A. O. \& Kolomiiets, I. A. (2018). Adaptacija stanu nespecifichnoï rezistentnosti organizmu kachok v umovah stresu pri vkljuchenni v racion probiotichnih dobavok. Naukovyi visnyk LNUVMB imeni S.Z. Gzhytskoho, 20(87), 32-38. doi: 10.15421/nvlvet8706 (in Ukrainian).

Pavlova, I. (2015). Effect of probiotics on doxycycline disposition in gastro-intestinal tract of poultry. Bulgarian Journal of Veterinary Medicine, 18(3), 248257. doi: 10.15547/bjvm.908.

Stojanovskij, V. G., Kolomiec, I. A., Garmata, L. S., \& Kamracka, O. I. (2018). Zmini morfofunkcionalnogo stanu organiv endokrinnoi ta imunnoi sistem perepeliv promislovogo viroshhuvannja za dii stresu. Fiziologichnij zhurnal, 64(1), 25-33. doi: 10.15407/fz64.01.025 (in Ukrainian).

Olubodun, J., Zulkifli, I., Hair-Bejo, M., Kasim, A., \& Soleimani, A. F. (2015). Physiological response of glutamine and glutamic acid supplemented broiler chickens to heat stress. European Poultry Science, 7982. doi: 10.1399/eps.2015.87.

Gutyj, B, Leskiv, K., Shcherbatyy, A., Pritsak, V., Fedorovych, V., Fedorovych, O., Rusyn, V., \& Kolomiiets, I. (2017). The influence of Metisevit on biochemical and morphological indicators of blood of piglets under nitrate loading. Regul. Mech. Biosyst. 8(3), 427-432. doi: 10.15421/021766.

Kapustian, A., Cherno, N., Stankevich, G., Kolomiiets, I., Matsjuk, O., Musiy, L. \& Slyvka, I. (2018). Determination of the enzyme destruction rational mode of biomass autolysate of lactic acid bacteria. EasternEuropean Journal of Enterprise Technologies, 1/11 (91), 63-68. doi: 10.15587/1729-4061.2018.120877.

Vlizlo, V. V., Fedoruk, R. S. \& Ratich, I. B. (2012). Laboratorni metodi doslidzhen u biologii, tvarinnictvi ta veterinarnij medicini: dovidnik (in Ukrainian).

Mohammed, A. A., Jacobs, J. A., Murugesan, G. R., \& Cheng, H. W. (2018). Effect of dietary synbiotic supplement on behavioral patterns and growth performance of broiler chickens reared under heat stress. Poultry Science, 97(4), 1101-1108. doi: $10.3382 / \mathrm{ps} / \mathrm{pex} 421$.

Nguyen, P. H., Greene, E., Donoghue, A., Huff, G., Clark, F. D., \& Dridi, S. (2016). A new insight into cold stress in poultry production. Adv. Food. Technol. Nutr. Sci. Open. J., 2(1), 1-2. doi: 10.17140/AFTNSOJ-2-124.

Hangalapura, B. N., Nieuwland, M. G. B., Buyse, J., Kemp, B., \& Parmentier, H. K. (2004). Effect of duration of cold stress on plasma adrenal and thyroid hormone levels and immune responses in chicken lines divergently selected for antibody responses. Poult. Sci., 83(10), 1644-1649. doi: $10.1093 / \mathrm{ps} / 83.10 .1644$.

Varkholiak, I., \& Gutyj, B. (2020). The influence of the preparation "Bendamin" on the morphological and biochemical indices of blood of rats in experimental modeling of heart failure. Ukrainian Journal of Veterinary and Agricultural Sciences, 3(1), 38-41. doi: 10.32718/ujvas3-1.07.

Tsiouris, V., Georgopoulou, I., Batzios, C., Pappaioannou, N., Ducatelle R., \& Fortomaris P. (2015). The effect of cold stress on the pathogenesis of necrotic enteritis in broiler chicks, Avian Pathology, 44(6), 430-435, doi: 10.1080/03079457.2015.1083094.

Qureshi, S., Khan, H. M., Mir, M. S., Raja, T. A., Khan, A. A., Ali, H., \& Adil, S. (2018). Effect of Cold Stress and Various Suitable Remedies on Performance of Broiler Chicken. J. World Poult. Res., 8(3), 66-73. 